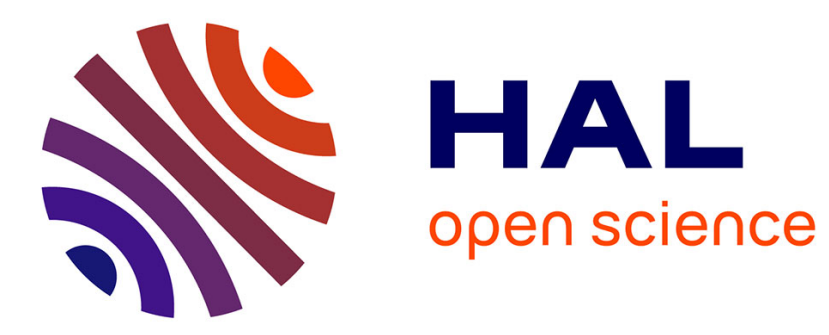

\title{
Perspective-Taking from a Social Neuroscience Standpoint
}

\author{
Malia F. Mason, C. Neil Macrae
}

\section{To cite this version:}

Malia F. Mason, C. Neil Macrae. Perspective-Taking from a Social Neuroscience Standpoint. Group Processes and Intergroup Relations, 2008, 11 (2), pp.215-232. 10.1177/1368430207088039 . hal00571684

\section{HAL Id: hal-00571684 https://hal.science/hal-00571684}

Submitted on 1 Mar 2011

HAL is a multi-disciplinary open access archive for the deposit and dissemination of scientific research documents, whether they are published or not. The documents may come from teaching and research institutions in France or abroad, or from public or private research centers.
L'archive ouverte pluridisciplinaire HAL, est destinée au dépôt et à la diffusion de documents scientifiques de niveau recherche, publiés ou non, émanant des établissements d'enseignement et de recherche français ou étrangers, des laboratoires publics ou privés. 


\title{
Perspective-Taking from a Social Neuroscience Standpoint
}

\author{
Malia F. Mason \\ Columbia University \\ C. Neil Macrae \\ University of Aberdeen
}

\begin{abstract}
A primary focus of research undertaken by social psychologists is to establish why perceivers fail to accurately adopt or understand other people's perspectives. From overestimating the dispositional bases of behavior to misinterpreting the motivations of out-group members, the message that emerges from this work is that social perception is frequently imperfect. In contrast, researchers from disciplines outside social psychology seek to identify the strategies and skill sets required to successfully understand other people's perspectives. These investigations attempt to identify the mechanisms through which perceivers intuit mental states that underlie behavior (e.g. wants, motivations, beliefs). In this article, we review findings from perspective-taking research in developmental psychology, primatology (i.e. primate cognition) and cognitive neuroscience. We then discuss why understanding how accurate perspectivetaking occurs may inform understanding of when and why this process fails.
\end{abstract}

KEYWORDS intentionality, person perception, perspective taking, social cognition, social cognitive neuroscience, social neuroscience, Theory of Mind (ToM)

Common-sense psychology works so well it disappears. (Fodor, 1987, p. 3)

AMONG the many contributions that social psychologists have made to the field of psychology, the identification of a slew of attributional biases that people exhibit is among the most prominent (Gilovich, 1993; Gilovich, Griffin, \& Kahneman, 2002; Miller \& Ross, 1975; Ross, Greene, \& House, 1977). As these findings readily attest, people's judgments and beliefs are colored in a variety of ways. Of considerable interest to researchers who study social perception is how these biases taint the process by which people explain the behavior of self and others (Heider, 1958; Jones \& Davis, 1965; Jones \& Harris, 1967; H.H. Kelley, 1967; Ross, 1977). By all accounts, there appears to be a huge discrepancy between how perceivers make sense of other people's behavior and how they intuit what motivates their own actions (Jones \& Nisbett, 1971; H.H. Kelley, 1967). Specifically, they tend to attribute other people's behavior to dispositional factors, while they see their own actions as being heavily influenced by the constraints of the situation. The influence this work had on social psychology cannot be overstated. One of the fundamental

\footnotetext{
$\overline{\text { Author's note }}$

Address correspondence to Malia Mason, Columbia Business School, Uris Hall, 3022

Broadway, New York, NY 10027, USA

[email: maliamason@columbia.edu]
} 
questions that has captivated the attention of social psychologists in the 40 years since Jones and Davis (1965) is, 'Why do people go awry when attempting to explain behavior?'

In light of the serious social consequences that arise from this bias, it is of little surprise that social psychologists have poured tremendous energy into elucidating its causes and identifying factors that encourage people to construe behavior more accurately. Among other things, the tendency to overestimate dispositional factors and underestimate situational constraints leads perceivers to make erroneous judgments about people's attitudes and beliefs (Jones \& Davis, 1965; Jones \& Harris, 1967), their capabilities (Ross, Amabile, \& Steinmetz, 1977), and their traits and dispositions (Nisbett, Caputo, Legant, \& Maracek, 1973; for a review, see Gilbert \& Malone, 1995). Furthermore, the tendency to overweight dispositional explanations and underweight situational ones is exacerbated when the target in question is from a stereotyped social group (Pettigrew, 1979).

One consequence of this emphasis, however, is that it neglects the frequency with which perceivers correctly intuit hidden mental states underlying behavior, and undervalues the skill required to comprehend intangible psychological states. Such an oversight is unfortunate since considering the underlying beliefs, proclivities and mental states of another is believed to be a cardinal mental capacity distinguishing humans from other social species (Tomasello, 1997; Tomasello \& Call, 1997). Moreover, considering how social attribution processes are successfully realized might constrain the social psychological models used to explain when and why people fail at this task.

Quite how humans effectively and efficiently ascribe mental states to other entities has been a topic of central importance to researchers in developmental psychology, primatology (i.e. primate cognition) and cognitive neuroscience for nearly 30 years. In general, researchers from these areas believe that to understand others' behavior in terms of invisible mental states like 'see', 'believe', 'want' and 'know', one needs to employ a folk psychology or a Theory of Mind (ToM) — an understanding of others as psychological beings having mental states and intentions that relate to their behavior (Leslie, 1987; Meltzoff, 1995; Perner, 1991; Premack \& Woodruff, 1978; Wellman, 1990). The primary goal of research in these fields has been identifying the mechanisms through which perceivers (both human and non-human primates) ascribe causal mental states to others' actions. In this article we review findings on the development of perspective-taking skills in humans, the homologues of these skills in non-human primates, and the biological underpinnings of these mechanisms. We conclude with a discussion of how findings from these disciplines might provide insight into when and why misattributions occur.

\section{Identifying goal-directed action}

Despite the apparent ease with which humans appear to make sense of other people's behavior, there are a number of significant obstacles that must be overcome before one can ascribe meaning to people's actions and identify the psychological causes of their behavior. Before one can even begin to decode the hidden mental states underlying another's action, one must first determine whether or not the witnessed behavior is intentional. This is particularly important in social interactions because how we respond to someone's actions (e.g. Brenda spilling water on your lap) hinges on whether we perceive the person as having intended the outcome (e.g. you wearing soaked slacks) or whether we think they had another goal in mind when they initiated the act (e.g. acquiring the salt placed just behind your water glass). Not only do our ascriptions of intentionality dictate how we respond to others' actions, they also determine how we construe and remember people's behavior. Evidence indicates that how we organize and attend to someone's movements largely depends on the goals we ascribe to their actions (Malle \& Knobe, 1997; Zadny \& Gerard, 1974; for a review see Baldwin \& Baird, 2001). Rather than encode every minute movement a person makes, we parse the endless stream of motion they exhibit into meaningful chunks of behavior. As several researchers have demonstrated, these 'chunks' — what the system 
considers meaningful-translate roughly into goals (Baird \& Baldwin, 2001; Goschke \& Kuhl, 1993; Newtson, 1973; Newston \& Engquist, 1976; Schank \& Abelson, 1977). It seems, therefore, that any complete understanding of how humans make sense of other people must incorporate an explanation of how perceivers ascribe intentionality to other people's actions (Malle, 1999; Malle, Moses, \& Baldwin, 2001).

What clues do perceivers rely on to determine when someone is acting in an intentional manner? Available evidence indicates that perceivers search for clues that indicate the observed action is related to a pre-existing goal. If little is previously known about either the target or the conditions that have given rise to a particular behavior, people base their assessments of volition on cues that the target's actions are (or are not) unfolding in relation to an object that has captured their interest (Baron-Cohen, 1994, 1995; Phillips, Baron-Cohen, \& Rutter, 1992). In other words, perceivers look for evidence that the action has a purpose or is about something and-equally important-that the agent is conscious of his or her actions. Of the possible cues people exploit to assess which objects in the environment are of interest to someone and to determine sentience, how the target individual allocates their attention, through posture and head and gaze direction, appears to be particularly useful (Argyle \& Cook, 1976; Butterworth \& Jarrett, 1991; Ellsworth \& Ludwig, 1972; Kleinke, 1986; Langton, Watt, \& Bruce, 2000). Perceivers tend to use head orientation and gaze direction when disambiguating the intentions underlying someone's behavior (Phillips et al., 1992), trying to understand complex social messages (Baron-Cohen, 1995), or when determining whether there is something of immediate interest in the environment that requires action (Driver et al., 1999; Friesen \& Kingstone, 1998; Langton \& Bruce, 1999).

\section{Findings from cognitive neuroscience}

Given the survival value in being able to rapidly detect the locus of another's interest, be it a potential mate or a predator, it is of little surprise that the human brain evolved a specialized system for detecting attention cues in others, for computing the direction of attention from these cues, and for ascribing meaning to subtle changes in head, gaze and posture direction (see Langton et al., 2000). Functional brain imaging data (both Positron Emission Tomography and functional magnetic resonance imaging) indicate that specialized visual mechanisms for detecting cues of engagement (e.g. eye gaze direction) and intentional movement exist in the superior temporal sulcus (STS; Hoffman \& Haxby, 2000; Puce, Allison, Bentin, Gore, \& McCarthy, 1998; see Langton et al., 2000). Interestingly, these mechanisms are quite sophisticated; they appear to be responsive not just to the physical properties contained in faces and eyes, but to the meaning they convey. For example, Pelphrey, Viola, and McCarthy (2003) found that the bloodoxygenation-level depending (BOLD) signal observed in this region as participants watched an animated man walk toward them (participants were wearing virtual reality goggles) depended not simply on how much the eyes moved but on the social meaning conveyed by the eye shifts. The response of the STS region to the animated man was much stronger when the target communicated social engagement, shifting his attention toward the participant, rather than social disengagement, when the man averted his eyes from the participant. As a number of brain imaging studies have demonstrated, this region seems to play a role in processing higher-level visual information that signals where other people's interest lies.

\section{Findings from single cell recordings in non-human primates}

Perhaps the most compelling demonstrations that the brain has evolved specialized mechanisms that code for attention and intentional action in others have emerged from studies that have used electrophysiological techniques (with nonhuman primates). Consistent with the findings obtained in functional brain imaging studies with humans, Perrett and colleagues (1985; Perrett, Mistlin, \& Chitty 1989; Perrett, Heitanen, Oram, Benson, \& Rolls, 1992; see Emery, 2000 for review) found a distinct population of cells 
in the macaque STS that was selective to changes in head orientation (i.e. the cells responded vigorously to changes in head direction but not to changes in the orientation of other objects), leading them to suggest that these cells enable an analysis of social attention, or signal where other individuals are directing their attention. What makes their proposal particularly compelling is that a portion of these cells appear to code for the abstract concept of 'attention in others'. For example, a cell that codes for 'attention being directed away' from the observing monkey will fire to any orientation of the target's head except a direct frontal view. If, however, the target head is displayed with a direct frontal view and the target averts its eyes to the left or to the right, the inhibition on the cell will be lifted. What this then suggests is that these cells rely on a conjunction of head, gaze and posture cues to determine another's referential intent (see Jellema, Baker, Wicker, \& Perrett, 2000; Perret et al., 1989, 1992; Wachsmuth, Oram, \& Perrett, 1994).

But cells in this region do not just code for the locus of others' attention; evidence indicates that there are populations of cells in the STS that are selective to limb movements in certain directions (e.g. reaching toward an object; presenting an object, etc. Perrett et al., 1985, 1998). Importantly, these cells are sensitive to the relationship between hand/limb movements and target objects. A manipulated action in the absence of a target object (e.g. pretending to grab an invisible cup) will not elicit firing in these cells; the cells' firing rate depends on the goal of the action (Jellema etal., 2000; Perrett et al., 1989). Particularly relevant to the present discussion is evidence that the firing patterns of cells that are responsive to the sight of hand and limb movements are conditional on the direction of attention of the agent performing the reaching. For example, a cell in the observing monkey that responds to an experimenter reaching out and grabbing an object will exhibit a reduced response if the experimenter performs the exact same action but attends away from the target object. This is taken as evidence that cell populations in the STS play a role in inferring the intentionality of animate actions by integrating higher-level visual information about the direction of attention and actions in others.

\section{Findings from developmental psychology}

It is widely believed among developmental psychologists that before a child can ascribe intentionality to another's behavior, they must possess an awareness that people have a psychological relationship with the objects that capture their interest and that the movements people make in relation to these objects are about something (Baron-Cohen, 1995; Leslie, 1994a). Put differently, they must come to understand that there is a psychological reason people engage (e.g. look at, grab, etc.) with things in their environment. Leslie (1994a) has suggested the capacity to construe people as perceiving the environment and pursuing goals emerges after children appreciate that when people engage with things in their environment, they are doing something meaningful.

Consistent with the possibility that the system for detecting intentionality is innate or 'hardwired' is evidence that precursor perspectivetaking skills emerge very early in infancy (see Baron-Cohen, 1994, 1995). Soon after birth, young infants are more likely to follow, and are more persistent in following, face-like shapes relative to other objects (Johnson, Dziurawiec, Ellis, \& Morton, 1991). Faces communicating social engagement elicit enhanced neural processing in newborns (Farroni, Csbira, Simon, \& Johnson, 2002) and 6-month-olds look two to three times longer at a face with gaze directed at them than to one looking away (Papousek \& Papousek \& Papousek, 1979). By 9-months of age, most babies can make and maintain eye contact with their care providers and by 12-months, look reliably to where someone else is looking (Corkum \& Moore, 1995; Hood, Willen, \& Driver, 1998; Scaife \& Bruner, 1975). These findings are interpreted as evidence that children are born predisposed to attend to information that is useful for assessing agency (Baron-Cohen, 1995).

Not only do infants appear to be born with an attraction to cues that signal intentionality, from a very early age they exhibit consummate skill 
at identifying the goals underlying people's actions. Woodward (1998) demonstrated that 5 month-olds habituate slower to a change in the goal of an action (i.e. what an agent is reaching toward) than to a change in the trajectory of an agent's reach toward an object, implying that, at this age, children are sensitive to the intentions that underlie people's movements. In a similar vein, Meltzoff (1995) demonstrated that 18-month-olds will re-enact what an adult intended to do (an intended action that failed or was never accomplished) rather than what the adult actually did, and that this was in contrast to the pattern of re-enactment they exhibited when watching a mechanical arm move in a goal-directed manner. Not only are they able to detect basic goals like reaching from an early age, recent evidence indicates that by 1 year of age, infants integrate information about the nature of the action with information about the identity or function of the object when perceiving others' behavior. For example, Spaepen and Spelke (2007) demonstrated that infants perceive a person reaching for a daisy as having the same basic goal as a person reaching for a rose (i.e. they construe goals in terms of the target object's basic level-'flower').

Furthermore, by the age of 2 children consistently utilize cues communicating people's referential intent. At 18 months, most children begin to expect that when a person expresses positivity toward an object (e.g., they look and smile at it), they will approach or act on the object that elicited this response (Spelke, Phillips, \& Woodward, 1995). Similarly, Baldwin and colleagues (Baldwin, 1991, 1993; Baldwin \& Moses, 1994) have demonstrated that 20-month olds understand that when a caregiver provides a verbal label for a target object (e.g. 'That is an 'apple', Mary') they are a referring to the item that they are currently attending to and not to some more perceptually salient stimulus in the environment (e.g. a clown hovering in the corner). By the second year of life children exhibit a firm understanding that people's movements are the instantiation of a goal and not simply a sequence of meaningless events (Woodward \& Markam, 1998; see Leslie, 1994b, p. 213, for a discussion of this issue).

\section{Perspective-taking}

Success in social interactions hinges on more than an awareness that people engage with their environment for psychological reasons and the capacity to detect intentional acts, however. To understand the behavior of others and effectively interact with them-to anticipate how they might react to something you say, for example-one must have insight into what they believe, think and feel and understand how these mental states relate to behavior.

How people use situational and dispositional factors to model another's perspective, and how they use the model to understand and predict behavior, are topics that have received burgeoning interest in developmental psychology, primatology and cognitive neuroscience over the last 30 years. Indeed, the scope of this work is too extensive to cover in detail in a single review article. In the current article we remain agnostic about which model best accounts for how people develop a ToM and focus instead on reviewing critical findings directly relevant to social attribution and highlighting hotly debated questions, such as whether non-human primates have a ToM and when children first exhibit the capacity to model other people's physical and mental perspectives. We point interested readers to excellent reviews for wider consideration of these issues (Baron-Cohen, 1995; Flavell, 1999; Frith \& Frith, 1999; Mitchell, Mason, Macrae, \& Banaji, 2006; Povinelli, 1993; Stone, 2006; Tomasello \& Call, 1997; Wellman \& Gelman, 1992).

\section{Findings from primate cognition (comparative psychology)}

In attempting to reconstruct the evolution of the human mind, primatologists have sought to establish precisely when social attribution emerged in the primate order, what environmental pressures may have contributed to the evolution of this ability, and what cognitive capacities are precursors to this skill. Among primatologists, it is generally believed that as primates began to live in larger coalitions, they were confronted by unique social challenges and that they adapted to these complexities by 
evolving specialized strategies for interacting with conspecifics (Byrne \& Whiten, 1988, 1990; for a review see Dunbar, 2003). In other words, primate intelligence developed as a response to a selective pressure for social expertise (Humphrey, 1976).

Results from primate studies generally suggest that the capacity for mental state attribution evolved quite recently in the history of the primate order leaving, as Povinelli described it, 'two fundamentally distinct groups of life: those who know that the mental world exists and those who do not' (1993, p. 494). For the most part, primatologists argue that chimpanzees and (possibly) apes are the only non-human primates who 'know about the mental world' and exhibit rudimentary perspective-taking behavior (de Waal, 1991; Gallup, 1982; Povinelli, 1993; Whiten \& Byrne, 1991). Although there continues to be considerable debate regarding this issue, most contend that the rest of the primate species (i.e. monkeys) behave and interact with each other in a purely non-mentalisitic manner. They can make associations between observable cues (e.g. another monkey directing its attention toward a tree) and a related behavior (e.g. the monkey climbing up the tree toward a dangling banana), but they never explicitly consider the cause underlying the agent's actions (e.g. the animal was famished) or use mentalistic state concepts to predict what others might do (see Heyes, 1998).

In their quest to assess the presence of perspective-taking faculties in non-human primates, primatologists have spent considerable time exploring the relationship between self-awareness and ToM reasoning. This is in no small part attributable to the impact of Gallup's (1970) demonstration that chimpanzees have self-recognition (they touched a dot of odorless red paint strategically placed on their forehead while they were anesthetized, when confronted by a mirror). In considering the implications of these findings, Gallup $(1970,1982)$ suggested that self-recognition is an indication of selfawareness, or the capacity of an organism to reflect on its own existence. Furthermore, he argued that introspection makes it possible for humans and chimpanzees to reason about their mental experiences and to speculate about the hidden mental states of others (Gallup, 1982; Meltzoff, 1995; see Povinelli, 1993 for a review). Subsequent to Gallup's (1970) study, it was demonstrated that the capacity for self-recognition is also present in orangutans (Lethmate \& Ducker, 1973) and absent in more than 20 species of monkeys, including gorillas (Ledbetter \& Basen, 1982; see Povinelli, 1987 however). Although these mirror-guided selfinspection findings are widely interpreted as reflecting the potential for select non-human primates to imagine themselves as others see them, this construal continues to be challenged on grounds that these demonstrations only prove these animals posses a 'body concept' (Heyes, 1998; but see Gallup, 1983).

Although Gallup's (1970) interpretations continue to be challenged, the results of several investigations are consistent with his suggestion that animals with the capacity to introspect possess rudimentary ToM skills. In a series of landmark studies, Premack and Woodruff (1978) found evidence that chimpanzees have an awareness of others' mental states and that they can use this information to adopt the viewpoint of another entity. Premack and Woodruff showed chimpanzee, Sarah, movies of human actors attempting to accomplish various tasks (e.g. escape from a cage). Before the movie reached completion (i.e. before the task was accomplished by the actor), the experimenters would stop the tape and administer a forcedchoice paradigm prompting Sarah to choose between two images-one that portrayed the solution to the current dilemma and a second that portrayed the solution to a different problem. Remarkably, Sarah picked the correct image at better than chance levels, indicating that she could intuit the goal underlying the experimenter's movements and identify the most appropriate means for attaining the desired outcome (see also Povinelli, Nelson \& Boysen, 1990; Uller \& Nichols, 2000).

Not only do primates exhibit an awareness of people's goals, a recent study by Warneken and Tomasello (2006) suggests that young chimpanzees will spontaneously volunteer assistance to an experimenter attempting a task that cannot 
be accomplished alone (e.g., the chimpanzees handed the experimenter items that were beyond the experimenter's reach). What is particularly remarkable is that this assistance appears to be contingent on the experimenter's current mental state. If the experimenter consciously dropped something and made no attempt to pick it up, the chimpanzee did not move to assist. However, if the experimenter feigned ignorance of the dropped object, the chimpanzee would retrieve the item for the experimenter (see also Tomasello \& Call, 1997).

It is important to note that not all of the scripted predicaments were met with the chimpanzee's unsolicited help. In fact, none of the tasks that required the chimpanzee to move a physical obstacle (e.g. open a cabinet door so that the experimenter could put an armful of books inside) were met by the animal's assistance. Rather than interpret this as evidence that chimpanzees lack the motivation to behave altruistically in these circumstances, they propose the animals lack the sophistication to intuit the need for assistance across varying goals, actions and situations. When Warneken and Tomasello (2006) compared the incidence of altruistic behavior of these chimpanzees to young human infants, they discovered that, although our nearest primate relatives exhibit the capacity to infer goals and an innate motivation to help, their cooperative dispositions are far surpassed by human infants, who helped regardless of the task context (see also Warneken, Chen, \& Tomasello, 2006). ${ }^{1}$

Complementing findings from the laboratory are documented examples of non-human primates exhibiting behaviors indicative of rudimentary perspective-taking faculties in their natural social environments. For example, field studies have reported that when two chimpanzees recently embroiled in conflict exhibit reluctance to reconcile their differences, a third party will occasionally initiate reconciliation by leading one opponent to the other (Cheney \& Seyfarth, 1986; Cheyney, Seyfarth, \& Smuts, 1986). There are several documented examples of non-human primates exhibiting cooperative behavior, which requires one to recognize that a task requires collaboration and that one has the capacity to work collectively to solve a problem (de Waal, 1982; Boesch \& Boesch, 1990). In fact, recent evidence indicates that before launching a cooperative endeavor, chimps will assess the collaborative capacities (e.g. the knowledge base, skill set) of potential teammates. For example, Melis, Hare, and Tomasello (2006) recently demonstrated that when confronted by a task that requires cooperation, chimpanzees solicit help from the most effective partners (e.g. the one that demonstrated the highest success rate on the previous day).

Perhaps the most compelling evidence that non-human primates spontaneously model the perspectives of others is their use of tactical deception. The know-how to mislead, direct and subtly manipulate others for personal gain-'Machiavellian intelligence' (Humphrey, 1976: Whiten \& Byrne, 1988, 1997)—is believed to have emerged as a consequence of living in complex social groups, where competition for limited resources can be avoided if an animal misrepresents a situation, using its normal behavioral repertoire, in such away that is advantageous to the animal (Byrne \& Whiten, 1988). Evidence indicates this phenomenon is actually widespread in non-human primates (Whiten \& Byrne, 1988), who commonly conceal things they value by hiding them or by inhibiting interest in the item, particularly if they are in the presence of a higher ranking monkey. Hare and colleagues (Hare, Call, \& Tomasello, in press), for example, have evidence that non-human primates take extra caution to retrieve food they know others are unaware of. Santos, Nissen, \& Ferrugia, (2007) have demonstrated that rhesus monkeys know what others can hear and-if given an option-will choose treats from a container that makes less noise when overturned.

It is also common for non-human primates to strategically attract another monkey's attention with calls or to distract their attention from something desirable using points or looks (Byrne \& Whiten, 1988; Whiten \& Byrne, 1988). Woodruff and Premack (1979) demonstrated that chimpanzees selectively deceive competitorsdirecting them away from an overturned container concealing food by pointing to one that is empty, and helping cooperating experimenters 
who share food by pointing to the container with the hidden treat. Finally, there is anecdotal evidence that chimpanzees strategically hide cues that might expose inopportune mental states. For example, de Waal (1982) described a chimpanzee that hid an external manifestation of fear (a fear grin) from another chimpanzee with whom he was in a dominance struggle, by placing his hand over his mouth. At the very least, these findings suggest the animals have physical perspective-taking skills (i.e. they know what others see is important), they understand that other animals share interests in certain items, and they have the wherewithal to casually and subtly manipulate another's behavior by giving them false impressions (Byrne \& Whiten, 1988; Cheney et al., 1986; Whiten \& Byrne, 1988).

\section{Findings from developmental psychology}

Paralleling the progress primatologists have made in specifying when precursors of mental state attribution emerged in the phylogenic order (and which social factors created selective pressure for this capacity), developmental psychologists have made considerable headway in understanding the ontogeny of these skills in human infants. Over the last three decades, they have advanced our understanding of when the precursors of these skills emerge, which general cognitive capacities need to be in place for mental attribution skills to develop (see Wellman, 1990; Perner, 1991 for a review), and which particular mental states infants develop an awareness of first (e.g. Hadwin \& Perner, 1991; Wellman, 1990).

Among developmental psychologists it is generally assumed that young children are born cognitively egocentric, or unaware that peopleincluding themselves-have differing physical and mental perspectives (cf. Flavell, 1999). Before the age of 3 , children generally fail at tasks that require 'person-reading'-assessments of another's desires or beliefs (Flavell \& Miller, 1998; Fodor, 1992; Gopnik \& Astington, 1988; Leslie, 1987). This incapacity is apparent in the problems children have with perspective-taking tasks, such as the False Belief Paradigm (Wimmer \& Perner, 1983). In perhaps the most popular version of this task a child is shown a box of candies and asked what the box contains. After the child responds, 'candy' the experimenter reveals to the child that, in fact, the box contains crayons. The experimenter then asks the child what another child, who has not yet been shown the true contents of the box, thinks it contains. Most 5-year-olds asked this question understand that just as they were deceived by the appearance of the crayon container, others will guess that the box contains 'candy'. In contrast, the majority of 3-year-olds respond 'crayons'. This is evidence that at this stage children are unaware that people can have beliefs that are false or inconsistent with reality (Wellman, Cross, \& Watson, 2001). Not only do they fail to recognize this about others, when prompted to indicate what they had initially believed was in the candy box, most 3-year-olds reply, 'crayons', suggesting that they have difficulty constructing even their own past perspectives (cf. Gopnik \& Astington, 1988).

Although at age 3 most children still struggle to construe others in terms of mental states like beliefs, the precursors of this capacity actually emerge when children are infants. Within the first few months of life, infants begin to follow the direction of an adult care provider's line of gaze (Scaife \& Bruner, 1975). Between 6 and 18 months, they begin to exhibit 'checking behavior', alternating their viewpoint between the caregiver and the direction in which the caregiver is attending (Butterworth \& Jarrett, 1991). Once these skills are polished, children begin to establish joint visual attention (i.e. shared experiences of another object) and strategically manipulate the attention of others. Around 10 months, infants begin to use communicative gestures like pointing (Franco \& Butterworth, 1996) and exhibit behaviors-like social referencing (Striano \& Rochat, 2000). This indicates that they are aware people have mental states (e.g. desires) about objects to which they attend (Baron-Cohen, 1994; Gopnik \& Meltzoff, 1977). They also begin to act on objects in a manner consistent with other people's wants and needs (e.g. they will complete tasks that others initiated but failed to complete), suggesting they are able to intuit other people's intentions (Baldwin \& Moses, 1996; Behne, Carpenter, 
Call, \& Tomasello, 2005; Meltzoff, 1995; Repacholi \& Gopnik, 1997; Warneken \& Tomasello, 2006; Woodward, 1998).

By 1 year, children exhibit an increased capacity to reason non-egocentrically. They begin to engage in spontaneous role-taking and pretend play, both of which require children to put themselves in another's psychological perspective (Leslie, 1994b). Eighteen month-old children seem to be aware that people vary with respect to desires and wants. For example, Repacholi and Gopnik (1997) demonstrated that when prompted to feed a caregiver one of two food options, 18 month-old children will choose the item (e.g. broccoli) that they witnessed the caregiver responding positively toward (smiling at it) on a previous occasion, even though they themselves prefer the alternative item (e.g. crackers). Importantly, children appear able to construe others in terms of wants, needs and desires long before they construe them in terms of either true or false beliefs (Bartsch \& Wellman, 1995; Wellman, 1990). This asymmetry in time may arise because beliefs involve interpretations of the world whereas desires simply reflect people's attitudes toward things (i.e. they are non-representational; Astington \& Gopnik, 1991; Gopnik \& Wellman, 1994). Indeed, many people have suggested that 'desire psychology' is a precursor to 'belief psychology' (Wellman, 1990). It is not until the age of 4 or 5 that a child's capacity to explain another's behavior in terms of what they believe (e.g. Curtis ran out of gasoline because he (mistakenly) thought his tank was full) begins to rival with their capacity to explain people in terms of desire states (cf. Bartsch \& Wellman, 1995). Soon after, they begin to attribute personalities, mental states and emotions to Heider and Simmel (1944) shapes almost as readily as their adult counterparts (Berry \& Springer, 1993) and exhibit an understanding that at a single moment in time people can have competing desires (Rakoczy, Warneken, \& Tomasello, 2007).

\section{Findings from cognitiven neuroscience}

In the last five years, it has become increasingly common for researchers to use functional brain imaging techniques to understand more about how perspective-taking occurs within the brain. The ultimate goal of this work is to specify which strategies people use to make sense of other people's behavior (see Flavell, 1999 for a discussion of three popular theories of ToM development) and to ground these psychological models in neurobiology. At this stage, researchers have implicated a number of brain regions in mentalizing (e.g. temporoparietal junction, TPJ; STS; and medial prefrontal cortex, mPFC); however, it is still not clear what particular functions each of these regions subserve (for reviews, see Amodio \& Frith, 2006; Frith \& Frith, 1999; Gallagher \& Frith, 2003). As discussed in the previous section on intentionality ascription, it is likely that the STS plays a critical role in integrating cues indicative of intentional movement and ascribing meaning to them. Consistent with this possibility, several studies have reported activity in this area when people engage in mental state attribution (e.g. Gallagher et al., 2000; Grezes, Frith, \& Passingham, 2004).

While there is considerable debate about exactly how people infer hidden mental states (see Flavell, 1999; Saxe, Moran, Scholz, \& Gabrieli, 2006), in as much as mentalizing involves using the self as a basis for generating a psychological model for another (i.e. simulation; Harris, 1992; see Gallup, 1985), one would expect the involvement of the medial prefrontal cortices (W. M. Kelley et al., 2002; Macrae, Moran, Heatherton, Banfield, \& Kelley, 2003; Mitchell, Banaji, \& Macrae, 2005a; for review see Amodio \& Frith, 2006). There is some evidence consistent with this possibility. Goel, Grafman, Sadato, \& Hallett (1995) reported finding greater activity in this region when their participants assessed whether certain historical figures would know how to use specific technologies (e.g. Would a contemporary of Christopher Columbus know how to use a compass versus a CD player?). Both Gallagher et al. (2000) and Brunet, Sarfati, Hardy-Bayle, and Decety (2000) found greater activity in this region when people attributed intentions to characters depicted in cartoons, whereas Castelli, Happe, Frith, \& Frith (2000) reported greater activity in this region, in the STS and in the TPJ when participants attributed 
mental states to animated objects. More recently, it has been demonstrated that the mPFC is recruited when participants reflect on people performing various actions (Mason, Banfield, \& Macrae, 2004) or on people's psychological states (Mitchell, Banaji, \& Macrae, 2005b). Evidence also indicates that this region is recruited when people attempt to 'outsmart' an opponent in a game of 'rock, paper, scissors' (Gallagher, Jack, Roepstorff, \& Frith, 2002; McCabe, Houser, Ryan, Smith, \& Trouard, 2001) or when they play games that require an assessment of the cooperative intent of others (e.g. the Prisoner's Dilemma, the Ultimatum Game; Rilling, Sanfey, Aronson, Nystrom, \& Cohen, 2004). While further research is needed to clarify how each of these areas contributes to the perspective-taking process and whether these mechanisms are specific to mental state attribution, grounding these mechanisms in functional neuroanatomy will likely lead to a more complete understanding of how we detect intentional acts and construe them in terms of mental states.

One obvious question is whether there are any known cases of individuals with impairments in perspective taking. It has been suggested that impaired mentalizing is one of the hallmark features of autism (Baron-Cohen, 1995; BaronCohen, Leslie, \& Frith, 1985). Unlike their healthy infant counterparts, autistic infants show little interest in social stimuli such as faces (Osterling \& Dawson, 1994). They never exhibit a tendency to orient in the direction in which another is attending (Dawson, Meltzoff, Osterling, Rinaldi, \& Brown, 1998) nor do they manipulate other people's attention through pointing (Mundy, Sigman, Ungerer, \& Sherman, 1986). In fact, they appear to go to great lengths to avoid social engagement altogether (Hobson \& Lee, 1998). In contrast to healthy children, who begin to exhibit pretend play and demonstrate some understanding of pretense at around 2 years of age, autistic children never engage in imaginative play (Roeyers \& van BerckelaerOnnes, 1994). While normal children begin to exhibit an understanding that people can believe things that are inconsistent with reality at the age of 3 or 4 , it is typical for autistic children to fail at false belief tasks well into their teens (BaronCohen, Leslie, \& Frith, 1986). In attempting to characterize the impairments exhibited by individuals with autism (e.g. impaired empathic thinking, an absence of self-consciousness, an inability to detect sarcasm), several researchers have suggested that autistics never develop a complete ToM and consequently treat people as if they were objects (e.g. Phillips, Gomez, \& Baron-Cohen, S., 1995). Although they have some success construing others in terms of desires and needs, they are severely impaired with tasks that involve belief attribution (BaronCohen, 1991). Although it remains open to debate, most researchers would agree that the mentalizing impairments autistic children exhibit are independent of other general cognitive abilities (e.g. Leslie \& Thaiss, 1992) and reflect a specific impairment in mental state attribution.

\section{Conclusion}

What do the findings from studies that have taken a developmental, comparative or cognitive neuroscience approach to social attribution have to offer social psychology? One obvious answer is a means of constraining our theories of how people explain the behavior of others.

Developmental psychology is particularly useful in providing insight into the nature of mental state attribution in the absence of environmental influences. By taking a developmental approach, one can examine which social mechanisms and tendencies people are born with and which are learned. Just as importantly, it provides a good means for assessing how perspective-taking skills evolve in relation to developing language and working memory capacities, or whether 'person reading' depends on general cognitive faculties (cf. Perner \& Lang, 1999). Furthermore, it seems reasonable to suspect that the pattern of errors that young children make when attributing mental states to others bears some resemblance to the biases exhibited by adults. Given evidence that 'belief psychology' is more sophisticated or computationally difficult than 'desire psychology' (e.g. Wellman, 1990), one 
might reasonably expect, for example, that people are more likely to misconstrue actions when they are motivated by representation states, such as beliefs. Having knowledge of the ontogeny of perspective-taking skills sheds light on why perceivers struggle to construe people's responses to the world in terms of what they believe it is rather than what it actually is (Gopnik \& Astington, 1988; Perner, 1991).

The current article also reviews research on social attribution skills in non-human primates. In general, the results of these studies suggest that the ability to infer goals and to intuit perspectives is present in rudimentary form in some non-human primates. In contrast to humans, the mentalizing skills observed in our closest evolutionary relatives emerged in the absence of language or formal training. As such, comparative work provides a means for assessing these skills when they are fully developed, absent obscuring cultural influences (Yerkes, 1943). What is particularly useful about this approach is that it makes it possible to reconstruct the phylogenetic history of perspective-taking, or the evolution of ToM skills across time (see Tomasello, 1997; Tomasello \& Call, 1997). One can therefore isolate components of ToM reasoning and determine how the skill impacted the survival and reproductive success of the animal over time. Using the same logic, one also gains insight into which social mechanisms might have been selected against and why. Finally, by considering changes in social living arrangements across the phylogenic order-an increase in coalition size, for example-one gains clues about what adaptations would have been necessary.

Finally, cognitive neuroscience approaches provide insight into the biological basis of this capacity. Cognitive neuroscience approaches are often criticized on the basis that they merely tell us 'where' in the brain some task takes place (e.g. Willingham \& Dunn, 2003). Practically speaking, knowing 'where' these processing mechanisms take place can be extremely useful, because we already have a working knowledge base of the function, connections, and phylogeny of a vast number of cortical regions. In a typical brain imaging experiment, researchers test whether a specific cortical region (e.g. the mPFC) is recruited during a particular task (e.g. ascribing mental states to others) because the area in question has been previously implicated in a process (e.g. self-referencing, introspection) that is purported to contribute to the task (e.g. mental state ascription; Gallup, 1970). In other words, even if brain imaging techniques only reveal something about 'where' the task happens in the brain, they still have the capacity to inform existing psychological models of mental state attribution.

Clearly our interpretations of people's behavior are influenced by our nuanced experiences (Bartlett, 1932; Goffman, 1974). Dispositionalism varies by culture (cf. Miller, 1984; Morris \& Peng, 1994) and by people's implicit social beliefs (Dweck, Hong, \& Chiu, 1993). Yet the available evidence also suggests that humans may be born with specialized systems for detecting agency (Leslie, 1994a; Spelke et al., 1995) and innately endowed with other mechanisms that facilitate their ability to mentalize (Baron-Cohen, 1995; Leslie 1995). ToM in particular appears to have a strong genetic component, for it is well known that autism is a highly heritable disorder (Bailey, Palferman, Heavey, \& Le Couteur, 1998). One central challenge that remains is determining which aspects of perspectivetaking are universal and which components are shaped by environmental upbringing (Hughes et al., 2005; Vinden, 1996; Perner, Ruffman, \& Leekman, 1994).

We began the present review by suggesting that having an understanding of how people successfully adopt the viewpoint of another can provide insight into the circumstances under which they fail. Although the debate over how perspective-taking is accomplished continues, one popular view among developmental psychologists, primatologists and cognitive neuroscientists is that perceivers intuit the motivations underlying other people's actions and predict their behavior by first simulating how they themselves would think or feel in similar circumstances and then adapting this mental model to account for self-other differences which lead to diverging vantage points. If this account is valid, one might reasonably expect 
three general categories of perspective-taking errors to emerge. The first class of errors might arise when perceivers map their own perspective onto a target but fail to update the mental model to account for important distinguishing information and, consequently, overestimate the degree to which other people's viewpoints match their own (e.g. the 'false consensus effect'; Ross, Greene, \& House, 1977; 'Keith must be shopping at the mall because, like myself, he enjoys being up-to-date on the latest fashion trends'). A second class of inaccuracies might emerge when perceivers have a faulty model to begin with; that is, they misidentify the motivations and beliefs that give rise to the observed behavior in themselves and erroneously apply their model to infer the mental states underlying the behavior of others (e.g. 'I only eat cookies when I am hungry, Bree must be eating cookies because she is famished'). Lastly, errors of a third type might arise when a target is perceived as being so dissimilar from the self that simulation is deemed an inappropriate strategy and abandoned for rule-based generalizations (e.g. 'The elderly woman must be standing on the street corner because she's lost and confused about where she is'; cf. Ames, 2004).

Whether this taxonomy of errors is meaningful ultimately depends on the validity of the simulation account of perspective-taking. The goal in using this example was simply to demonstrate that understanding the process by which perceivers ascribe mental state to other's behavior is key to predicting the outcome of perceivers' attempts to make sense of others, whether their attributions are accurate or not.

\section{Notes}

1. Interested readers can find video clips which illustrate these tasks with both infants and chimpanzees at http://email.eva.mpg.de/ $\sim$ warneken/video.htm.

\section{References}

Ames, D. (2004). Inside the mind-reader's toolkit: Projection and stereotyping in mental state inference. Journal of Personality and Social Psychology, 87, 340-53.
Amodio, D., \& Frith, C. (2006). Meeting of minds: The medial frontal cortex and social cognition. Nature Neuroscience, 7, 268-277.

Argyle, M., \& Cook, M. (1976). Gaze and mutual gaze. Oxford, UK: Oxford University Press.

Astington, J. W., \& Gopnik, A. (1991). Theoretical explanations of children's understanding of the mind. Developmental Psychology, 9, 7-31.

Bailey, A., Palferman, S., Heavey, L., \& Le Couteur, A. (1998). Autism: The phenotypes in relatives. Journal of Autism and Developmental Disorders, 28, 369-392.

Baird, J. A., \& Baldwin, D. A. (2001). Making sense of human behavior: Action parsing and intentional inference. In B. F. Malle, L. J. Moses, \& D. A. Baldwin (Eds.), Understanding intentions and intentionality: Foundations of social cognition (pp. 193-206). Cambridge, MA: MIT Press.

Baldwin, D. A. (1991). Infants' contribution to the achievement of joint reference. Child Development, 62, 875-890.

Baldwin, D. A. (1993). Early referential understanding: Infants' ability to recognize referential acts for what they are. Developmental Psychology, 29, 832-843.

Baldwin, D. A., \& Baird, J. A. (2001). Discerning intentions in dynamic human action. Trends in Cognitive Sciences, 5, 171-178.

Baldwin, D. A., \& Moses, L. J. (1994). Early understanding of referential intent and attentional focus: evidence from language and emotion. In C. Lewis \& P. Mitchell (Eds.), Children's early understanding of mind: Origins and development (pp. 133-156). Hillsdale, NJ: Erlbaum.

Baron-Cohen, S. (1991). Do people with autism understand what causes emotion? Child Development, 62, 385-395.

Baron-Cohen, S. (1994). How to build a baby that can read minds: Cognitive mechanisms in mindreading. Cahiers de Psychologie Cognitive/ Current Psychology of Cognition, 13, 513-552.

Baron-Cohen, S. (1995). Mindblindness: An essay on autism and theory of mind. London: MIT Press.

Baron-Cohen, S., Leslie, A., \& Frith, U. (1985). Does the autistic child have a 'theory of mind'? Cognition, 21, 37-46.

Baron-Cohen, S., Leslie, A., \& Frith, U. (1986). Mechanical, behavioural and intentional understanding of picture stories in autistic children. British Journal of Developmental Psychology, 4, 113-125. 
Bartlett, F. C. (1932). Remembering: A study in experimental and social psychology. New York: Cambridge University Press.

Bartsch, K., \& Wellman H. M., (1995). Children talk about the mind. New York: Oxford University Press.

Behne, T., Carpenter, M., Call, J., \& Tomasello, M. (2005). Unwilling versus unable: Infants' understanding of intentional action. Developmental Psychology, 41, 328-337.

Boesch, C., \& Boesch, H. (1990). Tool use and tool making in chimpanzees. Folia Primatologica, 54, 86-89.

Berry, D. S., \& Springer, K. (1993). Structure, motion and preschoolers' perceptions of causality. Ecological Psychology, 5, 273-284.

Brunet, E., Sarfati, Y., Hardy-Bayle, M. C., \& Decety, J., (2000). A PET investigation of the attribution of intentions with a nonverbal task. NeuroImage 11, 157-166.

Butterworth, G., \& Jarrett, J.(1991). What minds have in common is space: Spatial mechanisms serving joint visual attention in infancy. British Journal of Developmental Psychology, 9, 55-72.

Byrne, R. W., \& Whiten, A. (1988). Machiavellian intelligence. New York: Oxford University Press.

Castelli, F., Happe, F., Frith, U., \& Frith, C. (2000). Movement and mind: A functional imaging study of perception and interpretation of complex intentional movement patterns. NeuroImage 12, 314-325.

Cheney, D. L., \& Seyfarth, R. M. (1986). The recognition of social alliances among vervet monkeys. Animal Behaviour, 34, 1722-1731.

Cheney, D. L., Seyfarth, R. M., \& Smuts, B. (1986). Social relationships and social cognition in nonhuman primates. Science, 234, 1361-1366.

Corkum, V., \& Moore, C. (1995). Development of joint visual attention in infants. In C. Moore \& P. J. Dunham (Eds.), Joint attention: Its origins and role in development (pp. 61-84). Hillsdale, NJ: Erlbaum.

Dawson, G., Meltzoff, A. N., Osterling, J., Rinaldi, J., \& Brown, E. (1998). Children with autism fail to orient to naturally occurring social stimuli. Journal of Autism and Developmental Disorders, 28, 479-485.

de Waal, F. (1982) Chimpanzee politics. London: Jonathan Cape.

de Waal, F. (1991) Complementary methods and convergent evidence in the study of primate social cognition. Behaviour, 118, 297-320.

Driver, J., Davis, G., Ricciardelli, P., Kidd, P., Maxwell, E., \& Baron-Cohen, S. (1999). Gaze perception triggers reflexive visuospatial orienting. Visual Cognition, 6, 509-540.

Dunbar, R. I. M. (2003). The social brain: Mind, language, and society in evolutionary perspective. Annual Review of Anthropology, 32, 163-181.

Dweck, C. S., Hong, Y., \& Chiu, C. (1993). Implicit theories and individual differences in the likelihood and meaning of dispositional inference. Personality and Social Psychology Bulletin, 19, 644-656.

Ellsworth, P. C., \& Ludwig, L. M. (1972). Visual behavior in social interaction. Journal of Communication, 22, 375-403.

Emery, N. J. (2000). The eyes have it: The neuroethology, function and evolution of social gaze. Neuroscience and Behavioral Reviews, 24, 581-604.

Farroni, T., Csbira, G., Simon, F., \& Johnson, M. H. (2002). Eye contact detection in humans from birth. Proceedings of the National Academy of Sciences, USA, 99, 9602-9605.

Flavell, J. H., \& Miller, P. H. (1998). Social cognition. In D. Kuhn \& R. S. Siegler (Eds.), Handbook of child psychology: Vol. 2. Cognition, perception and language (pp. 851-898). New York: Wiley.

Flavell, J. H. (1999). Cognitive development: Children's knowledge about the mind. Annual Review of Psychology, 50, 21-45.

Fodor, J. (1987). Psychosemantics: The problem of meaning in the philosophy of mind. Cambridge, MA: MIT Press.

Fodor, J. (1992). A theory of the child's theory of mind. Cognition, 44, 283-296.

Franco, F., \& Butterworth, G. (1996). Pointing and social awareness: Declaring and requesting in the second year. Journal of Child Language, 23, 307-336.

Friesen, C. K., \& Kingstone, A. (1998). The eyes have it! Reflexive orienting is triggered by nonpredictive gaze. Psychonomic Bulletin and Review, 5, 490-495.

Frith, C. D., \& Frith, U. (1999). Interacting minds: A biological basis. Science, 286, 1692-1695.

Gallagher, H. L., \& Frith, C. D. (2003). Functional imaging of 'theory of mind'. Trends in Cognitive Sciences, 7, 77-83.

Gallagher, H. L., Happé, F., Brunswick, N., Fletcher, P. C., Frith, U., \& Frith, C. D. (2000). Reading the mind in cartoons and stories: An fMRI study of 'theory of mind' in verbal and nonverbal tasks. Neuropsychologia, 38, 11-21. 
Gallagher, H. L., Jack, A. I., Roepstorff, A., \& Frith, C. D. (2002). Imaging the intentional stance in a competitive game. Neuroimage, 16, 814-821.

Gallup, G. G. (1970). Chimpanzees: Selfrecognition. Science, 167, 86-87.

Gallup, G. G. (1982). Self-awareness and the emergence of mind in primates. American Journal of Primatology, 2, 237-248.

Gallup, G. G., Jr. (1983). Toward a comparative psychology of mind. In R. L. Mellgren (Ed.), Animal cognition and behavior (pp. 473-510). New York: North-Holland.

Gallup, G. G. (1985). Do minds exist in species other than our own? Neuroscience Biobehavioral Reviews, 9, 631-641.

Gilbert, D. T., \& Malone, P. S. (1995). The correspondence bias. Psychological Bulletin, 117, 21-38.

Gilovich, T. (1993). How what we know isn't so: The fallibility of human reason in everyday life. New York: Free Press.

Gilovich, T., Griffin, T., \& Kahneman, D. (2002). Heuristics and biases: The psychology of intuitive judgment. New York: Cambridge University Press.

Goel, V., Grafman, J., Sadato, N., \& Hallett, M. (1995). Modeling other minds. NeuroReport, 6, 1741-1746.

Goffman, E. (1974). Frame analysis: An essay on the organization of experience. Cambridge, MA: Harvard University Press.

Gopnik, A., \& Astington, J. W. (1988). Children's understanding of representational change and its relation to the understanding of false belief and the appearance-reality distinction. Child Development, 59, 26-37.

Gopnik, A., \& Meltzoff, A. N. (1997). Words, thoughts, and theories. Cambridge, MA: MIT Press.

Gopnik, A., \& Wellman, H. M. (1994) The theory theory. In L. A. Hirschfeld \& S. A. Gelman (Eds.), Mapping the mind: Domain specificity in cognition and culture (pp. 257-293). New York: Cambridge University Press.

Goschke, T., \& Kuhl, J. (1993). Representation of intentions: Persisting activation in memory. Journal of Experimental Psychology: Learning, Memory E Cognition, 19, 1211-1226.

Grezes, J., Frith, C., \& Passingham, E. (2004). Brain mechanisms for inferring deceit in actions of others. Journal of Neuroscience, 24, 5500-5505.

Hadwin, J., \& Perner, J. (1991). Pleased and surprised: Children's cognitive theory of emotion. British Journal of Developmental Psychology, 9, 215-234.
Hare, B., Call, J., \& Tomasello, M. (in press). Chimpanzees deceive a human by hiding. Cognition, 101, 495-514.

Harris, P. L. (1992). From simulation to folk psychology: The case for development. Mind and Language, 7, 120-144.

Heider, F. (1958). The psychology of interpersonal relations. New York: Wiley.

Heider, F., \& Simmel, M. (1944). An experimental study of behavior. American Journal of Psychology, 57, 243-259.

Heyes, C. M. (1998). Theory of mind in nonhuman primates. Behavioral and Brain Sciences, 21, 101-114.

Hobson, R. P., \& Lee, A. (1998). Hello and goodbye: A study of social engagement in autism. Journal of Autism and Developmental Disorders, 28, 117-127.

Hoffman, E. A., \& Haxby, J. V. (2000). Distinct representations of eye gaze and identity in the distributed human neural system for face perception. Nature Neuroscience, 3, 80-84.

Hood, B. M.,Willen, J. D., \& Driver, J. (1998). Adult's eyes trigger shifts of visual attention in human infants. Psychological Science, 9, 131-134.

Hughes, C., Jaffee, S. R., Happe, F., Taylor, A., Caspi, A., \& Moffitt, T. E. (2005). Origins of individual differences in theory of mind: From nature to nurture? Child Development, 76, 356-370.

Humphrey, N. K. (1976). The social function of intellect. In P. P. G. Bateson \& R. A. Hinde (Eds.), Growing points in ethology (pp. 303-317). Cambridge, UK: Cambridge University Press.

Jellema, T., Baker, C. I., Wicker, D. I., \& Perrett, D. I. (2000). Neural representation for the perception of intentionality of actions. Brain and Cognition, 44, 280-302.

Johnson, M. H., Dziurawiec, S., Ellis, H., \& Morton, J. (1991) . Newborns' preferential tracking of face-like stimuli and its subsequent decline. Cognition, 40, 1-19.

Jones, E. E., \& Nisbett, R. E. (1971). The actor and observer: Divergent perceptions of the causes of behavior. In E. E. Jones, D. E. Kanouse, H. H. Kelley, R. E. Nisbett, S. Valins, \& B. Weiner (Eds.), Attribution: Perceiving the causes of bahvior (pp. 79-94). Morristown, NJ: General Learning Press.

Jones, E. E., \& Davis, K. E. (1965). A theory of correspondent inferences: From acts to dispositions. In L. Berkowitz (Ed.), Advances in experimental social psychology (Vol. 2, pp. 219-226). New York: Academic Press. 
Jones, E. E., \& Harris, V. A. (1967). The attribution of attitudes. Journal of Experimental Social Psychology, 3, 1-24.

Kelley, H. H. (1967). Attribution theory in social psychology. In D. Levine (Ed.), Nebraska symposium on motivation (pp. 192-238). Lincoln, NE: University of Nebraska Press.

Kelley W. M., Macrae, C. N., Wyland, C., Calgar, S., Inati, S., \& Heatherton, T. (2002). Finding the self? An event-related fMRI study. Journal of Cognitive Neuroscience, 14, 785-794.

Kleinke, C. L. (1986). Gaze and eye contact: A research review. Psychological Bulletin, 100, 78-100.

Langton, S. R. H., \& Bruce, V. (1999). Reflexive visual orienting in response to the social attention of others. Visual Cognition, 6, 541-567.

Langton, S. R. H., Watt, R. J., \& Bruce, V. (2000). Do the eyes have it? Cues to the direction of social attention. Trends in Cognitive Sciences, 4, 50-59.

Leslie, A. M. (1987). Pretense and representation: The origins of 'theory of mind'. Psychological Review, 94, 412-426.

Leslie A. M. (1994a). ToMM, ToBY and agency: Core architecture and domain specificity. In L. A. Hirschfeld \& S. A. Gelman (Eds.), Mapping the mind: Domain specificity in cognition and culture (pp. 119-48). Cambridge, UK: Cambridge University Press.

Leslie, A. M. (1994b). Pretending and believing: Issues in the theory of ToMM. Cognition, 50, 211-238.

Leslie, A. M. (1995). A theory of agency. In D. Sperber, D. Premack, \& A. J. Premack (Eds.), Causal cognition: A multidisciplinary debate (pp. 121-141). Oxford, UK: Clarendon Press.

Leslie, A. M., \& Thaiss, L. (1992). Domain specificity in conceptual development: Neuropsychological evidence from autism. Cognition, 43, 225-251.

Lethmate, J., \& Ducker, G. (1973). Untersuchungen am sebsterkennen im spiegel bei orangutans einigen anderen affenarten [Self-recognition by orangutans and some other primates]. Zietschrift fur Tierpsychologies, 33, 248-269.

Macrae, C. N., Moran, J. M., Heatherton, T. F., Banfield, J. F., \& Kelley, W. (2003). Medial prefrontal activity predicts memory for self. Cerebral Cortex, 14, 647-654.

Malle, B. F. (1999). How people explain behavior: A new theoretical framework. Personality and Social Psychology Review, 3, 23-48.
Malle, B. F., \& Knobe, J. (1997). The folk concept of intentionality. Journal of Experimental Social Psychology, 33, 101-121.

Malle, B. F., Moses, L. J., \& Baldwin, D. A. (2001). Intentions and intentionality: Foundations of social cognition. Cambridge, MA: MIT Press.

Mason, M. F., Banfield, J. F., \& Macrae, C. N. (2004). Thinking about actions: The neural substrates of person knowledge. Cerebral Cortex, 14, 209-214.

McCabe, K., Houser, D., Ryan, L., Smith, V., \& Trouard, T. (2001). A functional imaging study of cooperation in two-person reciprocal exchange. Proceedings of the National Academy of Science, US A, 98, 11832-11835.

Melis, A. P., Hare, B., \& Tomasello, M. (2006). Engineering cooperation in chimpanzees: Tolerance constraints on cooperation. Animal Behavior, 72, 275-286.

Meltzoff, A. N. (1995). Understanding the intentions of others: Re-enactment of intended acts by 18-month old children. Developmental Psychology, 31, 838-850.

Miller, D. T., \& Ross, M. (1975).Self-serving biases in the attribution of causality: Fact or fiction? Psychological Bulletin, 82, 213-225.

Miller, J. G. (1984). Culture and the development of everyday social explanation. Journal of Personality and Social Psychology, 46, 961-978.

Mitchell, J. P., Banaji, M. R., \& Macrae, C. N. (2005a). The link between social cognition and self-referential thought in the medial prefrontal cortex. Journal of Cognitive Neuroscience, 17, 1306-1315.

Mitchell, J. P., Banaji, M. R., \& Macrae, C. N. (2005b). General and specific contributions of the medial prefrontal cortex to knowledge about mental states. NeuroImage, 28, 757-762.

Mitchell, J. P., Mason, M. F., Macrae, C. N., \& Banaji, M. R. (2006). Thinking about others: The neural substrates of social cognition. In J. T. Cacioppo, P. S. Visser, \& C. L. Pickett (Eds.), Social neuroscience: People thinking about people (pp. 63-82). Cambridge, MA: MIT Press.

Morris, M. W., \& Peng, K. (1994). Culture and cause: American and Chinese attributions for social and physical events. Journal of Personality and Social Psychology, 67, 949-971.

Mundy, P., Sigman, M.D., Ungerer, J., \& Sherman, T. (1986). Defining the social deficits of autism: The contribution of non-verbal communication measures. Journal of Child Psychology and Psychiatry, 27, 657-669. 
Newtson, D. (1973) Attribution and the unit of perception of ongoing behavior. Journal of Personality and Social Psychology, 28, 28-38.

Newtson, D., \& Engquist, G. (1976). The perceptual organization of ongoing behavior. Journal of Experimental Social Psychology, 12, 436-450.

Nisbett, R. E., Caputo, C., Legant, P., \& Maracek, J. (1973). Behavior as seen by the actor and as seen by the observer. Journal of Personality and Social Psychology, 27, 154-164.

Osterling, J., \& Dawson, G. (1994). Early recognition of children with autism: A study of first birthday home videotapes. Journal of Autism and Developmental Disorders, 24, 247-257.

Papousek, M., \& Papousek, H. (1979). Early ontogeny of human social interaction: Its biological roots and social dimensions. In M. Cranach, K. Foppa, W. Lepenies, \& P. Ploog (Eds.), Human ethology: Claims and limits of a new discipline (pp. 63-85). Cambridge, UK: Cambridge University Press.

Pelphrey, K. A.,Viola, R. J., \& McCarthy, G. (2003). When strangers pass: Processing of mutual and averted social gaze in the superior temporal sulcus. Psychological Science, 15, 598-603.

Perner, J. (1991). Understanding the representational mind. Cambridge, MA: MIT Press.

Perner, J., \& Lang, B. (1999). Development of theory of mind and executive control. Trends in Cognitive Sciences, 3, 337-344.

Perner, J., Ruffman, T., \& Leekman, S. R. (1994). Theory of mind is contagious: You catch it from your sibs. Child Development, 65, 1228-1238.

Perrett, D. I., Harries, M. H., Bevan, R., Thomas, S., Benson, P. J., Mistlin, A. J. et al. (1998). Frameworks of analysis for the neural representation of animate objects and actions. Journal of Experimental Biology, 146, 87-113.

Perrett, D. I., Hietanen, J. K., Oram, M.W., Benson, P. J., \& Rolls, E. T. (1992). Organization and functions of cells responsive to faces in the temporal cortex. Philosophical Transactions of the Royal Society: Biological Science, 335, 23-30.

Perrett, D. I., Mistlin, A. J., \& Chitty, A. J. (1989). Visual neurones responsive to faces. Trends in Neurosciences, 10, 358-364.

Perrett, D. I., Smith, P. A. J., Mistlin, A. J., Chitty, A. J., Head, A. S., Potter, D. D. et al. (1985). Visual analysis of body movements by neurones in the temporal cortex of the macaque monkey: A preliminary report. Behavioural Brain Research, 16, 153-170.
Pettigrew, T. F. (1979). The ultimate attribution error: Extending Allport's cognitive analysis of prejudice. Personality and Social Psychology Bulletin, 5, 461-476.

Phillips, W., Baron-Cohen, S., \& Rutter, M. (1992). The role of eye contact in goal detection: Evidence from normal infants and children with autism or mental handicap. Developmental and Psychopathology, 4, 375-383.

Phillips, W., Gomez, J. C., \& Baron-Cohen, S. (1995). Treating people as objects, agents or 'subjects': How young children with autism make requests. Journal of Child Psychology and Psychiatry, 36, 1383-1398.

Povinelli, D. J. (1987). Monkeys, apes, mirrors and minds: The evolution of self-awareness in primates. Human Evolution, 2, 493-509.

Povinelli, D. J. (1993). Reconstructing the evolution of mind. American Psychologist, 48, 493-509.

Povinelli, D. J., Nelson, K. E., \& Boysen, S. T. (1990). Inferences about guessing and knowing by chimpanzees. Journal of Comparative Psychology, 104, 203-210.

Premack, D., \& Woodruff, G. (1978). Does the chimpanzee have a theory of mind? Behavioral and Brain Sciences, 3, 615-636.

Puce, A., Allison, T., Bentin, S., Gore, J. C., \& McCarthy, G. (1998). Temporal cortex activation in humans viewing eye and mouth movements. Journal of Neuroscience, 18, 2188-2199.

Rakoczy, H., Warneken, F., \& Tomasello, M. (2007). 'This way!', 'No! That way!'-3-yearolds know that two people can have mutually incompatible desires. Cognitive Development, 22, 47-68.

Repacholi, B. M., \& Gopnik, A.(1997). Early reasoning about desires: Evidence from 14and 18-month-olds. Developmental Psychology, 33, 12-21.

Rilling, J. K., Sanfey, A. G., Aronson, J. A., Nystrom, L. E., \& Cohen, J. D. (2004). The neural correlates of theory of mind within interpersonal interactions. Neuroimage, 22, 1694-1703.

Roeyers, H., \& van Berckelaer-Onnes, I. A. (1994). Play in autistic children. Communication and Cognition, 27, 349-359.

Ross, L. D. (1977). The intuitive psychologist and his shortcomings: Distortions in the attribution process. In L. Berkowitz (Ed.), Advances in experimental social psychology (Vol. 10, pp. 173-220). New York: Random House. 
Ross, L. D., Amabile, T. M., \& Steinmetz, J. L. (1977) Social roles, social control and biases in social perception, Journal of Personality and Social Psychology, 35, 485-494.

Ross, L. D., Greene, D., \& House, P. (1977). The false consensus effect: An egocentric bias in social perception and attributional processes. Journal of Experimental Social Psychology, 13, 279-301.

Santos, L. R., Nissen, A. G., \& Ferrugia, J. A. (2007). Rhesus monkeys, Macaca mulatta, know what others can and cannot hear. Animal Behavior, 71, 1175-1181.

Saxe, R., Moran, J. R., Scholz, J., \& Gabrieli, J. (2006). Overlapping and non-overlapping brain regions for theory of mind and self reflection in individual subjects. Social Cognitive and Affective Neuroscience, 1, 229-234.

Scaife, M., \& Bruner, J. S. (1975). The capacity for joint visual attention in the infant. Nature, 253, 265-266.

Schank, R. C., \& Abelson, R .P. (1977) Scripts, plans, goals and understanding: An inquiry into human knowledge structures. Hillsdale, NJ: Erlbaum.

Spaepen, E., \& Spelke, E. S. (2007). Will any doll do? 12-month-olds' reasoning about goal objects. Cognitive Psychology, 54, 133-154.

Spelke, E. S., Phillips, A., \& Woodward, A. L. (1995). Infants' knowledge of object motion and human action. In D. Sperber, D. Premack, \& A. James (Eds.), Causal cognition: A multidisciplinary debate (pp. 44-78). New York: Oxford University Press.

Stone, V. E. (2006). Theory of mind and the evolution of social intelligence. In J. T. Cacioppo, P. S. Visser, \& C. L. Pickett (Eds.), Social neuroscience: People thinking about people (pp. 63-82). Cambridge, MA: MIT Press.

Striano, T., \& Rochat, P. (2000). Emergence of selective social referencing in infancy. Infancy, 1, 253-264.

Tomasello, M. (1997). The cultural origins of human cognition. Cambridge, MA: Harvard University Press.

Tomasello, M., \& Call, J. (1997). Primate cognition. New York: Oxford University Press.

Uller, C., \& Nichols, S. (2000). Goal attribution in chimpanzees. Cognition, 76, B27-B34.

Vinden, P. G. (1996). Junin Quecha children's understanding of mind. Child Development, 67, 1707-1716.

Wachsmuth, E., Oram, M. W., \& Perrett, D. I.(1994). Recognition of objects and their component parts: Responses of single units in the temporal cortex of the macaque. Cerebral Cortex, 4, 509-522.

Warneken, F., Chen, F., \& Tomasello, M. (2006). Cooperative activities in young children and chimpanzees. Child Development, 77, 640-663.

Warneken, F., \& Tomasello, M. (2006). Altruistic helping in human infants and young chimpanzees. Science, 311, 1301-1303.

Wellman, H. M. (1990). The child's theory of mind. Cambridge, MA: MIT Press.

Wellman, H. M., Cross, D., \& Watson, J. (2001). Meta-analysis of theory-of-mind development: The truth about false belief. Child Development, 72, 655-684.

Wellman, H. M., \& Gelman, S. A. (1992). Cognitive development: Foundational theories of core domains. Annual Review of Psychology, 43, 337-375.

Whiten, A., \& Byrne, R. W. (1988) Tactical deception in primates. Behavioral and Brain Sciences, 11, 233-273.

Whiten, A., \& Byrne, R. W. (1997). Machieveillian intelligence II: Extensions and evaluations. New York: Cambridge University Press.

Whiten, A., \& Byrne, R. W. (1991). The emergence of metarepresentation in human ontogeny and primate phylogeny. In A. Whiten (Ed.), Natural theories of mind (pp. 267-283).

Willingham, D. T., \& Dunn, E. W. (2003). What neuroimaging and brain localization can do, cannot do and should do for social psychology. Journal of Personality and Social Psychology, 85, 662-671.

Wimmer, H., \& Perner, J. (1983). Beliefs about beliefs: Representation and constraining function of wrong beliefs in young children's understanding of deception. Cognition, 13, 103-128.

Woodward, A. L. (1998). Infants selectively encode the goal object of an actor's reach. Cognition, 69, 1-34.

Woodward, A. L., \& Markman, E. M. (1998). Early word learning. In D. Kuhn \& R. S. Siegler (Eds.), Handbook of child psychology: Vol. 2. Cognition, perception and language (pp. 371-420). New York: Wiley.

Yerkes, R. M. (1943). Chimpanzees: A laboratory colony. New Haven, CT: Yale University Press.

Zadny, J., \& Gerard, H. B. (1974). Attributed intentions and informational selectivity. Journal of Experimental Social Psychology, 10, 34-52. 


\section{Biographical notes}

MALIA MASON, PhD is an assistant professor of management at Columbia Business School.

Her research interests include social cognition, social neuroscience, perspective taking, person perception and mind wandering.
NEIL MACRAE, PhD, DSc is professor of psychology at the University of Aberdeen. His research interests include person perception and the neural correlates of social cognition. 